\title{
BLUE-LIGHT BRIGADES AND THE POLITICS OF BAD DRIVING
}

\section{$1 \quad$ Introduction}

The so-called blue-light brigade "bullies" who form part of the VIP Protection Unit continue to present a formidable danger to other road users and have become the controversial focus of media attention. (The VIP units are deployed to protect persons who qualify as VIPs ("Very Important Persons"). See, eg, "1 555 Police for 211 VIPS" 21 May 2010 Cape Argus; "DA Questions Massive VIP Protection Price Tag" 21 May 2012 Daily News (available Sabinet SA Media). See "Matric in Coma after Blue Light Crash" 7 November 2011 Beeld, for a report on Thomas Ferreira who was critically injured after being knocked down by an MEC's vehicle, http://www.news24. com/Tags/People/thomas_ferreira) (accessed 2012-07-17.) Notably in the Western Cape, the intention has been expressed to introduce provincial legislation in an attempt to curb incidents of VIP blue-light brigade bullying. In her State of the Province address on 19 February 2010, Helen Zille, Premier of the Western Cape, stated that:

"we don't believe that politicians should have special rights and privileges that
other citizens don't have. We share the public's disgust at being forced off the
road by blue light bullies escorting self-important politicians ... we will
therefore introduce legislation, in terms of our constitutional competencies for
provincial roads and traffic, as well as road traffic regulation, to prevent any
politician - from any sphere of government - using blue-light convoys and
sirens in the Western Cape, unless a genuine emergency arises." (State of
the Province Address: February 2010 Cape>Gateway, http://www.capegate
way.gov.za (accessed 2012-07-17). Also available http://www.westerncape.
gov.za/speech/state-province-address-february-2010 (accessed 2013-04-22).)

Although a Western Cape cabinet resolution was taken in November 2010 to the effect that blue lights and sirens were to be removed from provincial ministerial vehicles in the Western Cape, this decision does not have an impact on the other provinces. ("No Blue Lights for Western Cape Ministers", http://www.capegateway.gov.za (accessed 2012-07-17); also http://www. westerncape.gov.za/search/index.php?q=no+blue+lights+for+western+cape + ministers (accessed 2013-04-22). The Western Cape did introduce section $8(1)$ (b) regulating the use of blue lights in the Western Cape Provincial Road Traffic Bill, 2012 (Provincial Gazette Extraordinary 7025, dated 22 August 2012) for public comment. See also http://www.westerncape.gov.za/text /2012/9/Western\%20Cape\%20Provincial\%20\%20Road\%20\%20Traffic\%20A dministration.pdf (accessed 2013-04-22). Section 8(1)(b) reads: "the Minister may make regulations, not inconsistent with this Act or the National Road Traffic Act, in respect of - (b) Any restrictions in respect of the use of lamps emitting a blue light or of sirens on vehicles operated by any person. There is no other evidence to indicate that the national legislature or provinces have passed 
any acts or regulations applicable to the VIP Protection Unit or to persons engaged in civil protection.) In the absence of specific legislation relating to the VIP units, the purpose of this article is to attempt to shed light from a criminal-law perspective, on the key issue of how far the possible "immunity" enjoyed by VIP units extends where road users are bullied for right of way or are injured or killed (although the subject matter discussed in this article could also find application to other emergency vehicles such as ambulances and fire-brigades, the provisions which are focused on are those specifically relating to the blue-light brigades). Various offences will be investigated to establish under which provisions (if any) the VIP members may be held criminally accountable. This article will firstly analyse the road-traffic regulations and possible exemptions which may be applicable to VIP units. Secondly, the criminal liability of the VIP units will be examined with reference to some of the possible crimes and defences applicable. Lastly, constitutional issues in the context of blue-light brigades will be investigated.

\section{Possible statutory infractions in terms of the National Road Traffic Act 93 of 1996 and regulations}

The National Road Traffic Act 93 of 1996 (hereinafter "the NRTA") makes it an offence for any person to disobey road traffic signs or to exceed the speed limit (ss 58 and 59). The National Road Traffic Regulations of 2000 provided that it is an offence for a motor vehicle to be fitted with lamps which emit a blue light (s 176(3)(a) of R225 of 2000). This provision is not applicable to motor vehicles which are operated by members of the police or defence forces or by a traffic officer "in the execution of his or her duties" (s 176(3)(b)). Both the National Road Traffic Act 93 of 1996 and the National Road Traffic Regulations 2000 apply to members of the SAPS who operate vehicles that fall within the ambits of the definition of an "emergency vehicle". The vehicle must be equipped with a device which emits sound as well as with a lamp that must be used whenever the speed limit is exceeded. (S 60(b). See also R v Evans 1962 (3) SA 358 (SR); and S v Groep 2002 (1) SACR 538 (E).) A salient question is whether the blue-light brigade bullies are considered as members of the police force, as they would then be afforded a certain degree of immunity.

\section{The exemptions that would afford immunity to VIP units}

Sections $58(3)$ and 60 of the NRTA afford exemption to the drivers of firefighting vehicles, rescue vehicles and ambulances, to traffic officers carrying out their duties or to persons engaged in civil protection, who may disregard road rules or exceed the speed limit under certain circumstances.

The VIP-brigade members are not covered by the exemption provisions relating to civil protection. A person who is engaged in civil protection, may be fitted with a flashing green light and the VIP Units would consequently not fall within the ambits of these regulatory measures (see s 176(6) of the Civil Protection Act 67 of 1977; and see also s 3(1)(a) of the Civil Protection Act, 1977 read with s 64 of the Disaster Management Act 57 of 2002 and Proclamation R153 of 31 October 1994). 
The VIP units are members of the South African Police Services. (Hereinafter "SAPS". See Internal Question Paper No 11-2010 (2010-04-26), Parliamentary Monitoring Group Question 1245 http:www.pmg.org.za in this regard (accessed 2012-07-17), where Ms D Kohler-Barnard (DA) addresses the following questions to the Minister of Police (answers included): How many members of the SAPS are employed in the VIP Protection unit? (1555) How many individuals are receiving VIP protection? (211) What categories of people are entitled to VIP Protection? (The Executive at national and provincial levels (Ministers, Deputy Ministers, National Speaker, Chairperson of the National Council of Provinces, President of the Supreme Court of Appeal and their deputies, Judge Presidents, members of the Executive Councils and Speakers of provincial legislature).) It is clear that the VIP units are currently regulated by national legislation (see Schedules 1 and 2 to Proc R153 of 1994-10-31). This is apparent from an analysis of the provisions of the National Road Traffic Act 93 of 1996 and National Road Traffic Regulations of 2000 , which dictate that VIP blue-light brigade members may be included within the definition of traffic officers, by virtue of the fact that they fall under the auspices of the South African Police Services. (A traffic officer is defined in s 1 of the National Road Traffic Act 93 of 1996 as being "appointed in terms of s $3 A$ and any member of the service, and any member of a municipal police service, both as defined in section 1 of the South African Police Service Act 68 of 1995". In terms of the latter Act a "member" means: "any member of the Service referred to in $s$ 5(2), and including - (a) except for the purposes of any provision of this Act in respect of which the National Commissioner may otherwise prescribe, any member of the Reserve while such member is on duty in the Service; (b) any temporary member while employed in the Service; (c) any person appointed in terms of any other law to serve in the Service and in respect of whom the Minister has prescribed that he or she be deemed to be a member of the Service for the purposes of this Act; and (d) any person designated under $\mathrm{s}$ 29 as a member". The important point to note is that traffic officers and members of the South African Police Service are afforded a degree of immunity in terms of this exemption, subject to certain limitations. The police service forms part of the security services of the Republic in terms of $s$ 199(1) of the Constitution.) The Constitution of South Africa, 1996, makes provision for concurrent national and provincial legislative competence with regard to road-traffic regulation and the police force. (Schedule 4 Part A. This concurrent competence is, however, limited to Chapter 11 in the case of the police force. See ss 206-207 in this regard.)

In the meantime, one should bear in mind that, while the use of a blue light is sanctioned by the Road Traffic Regulations of 2000, there are some activities that would not be considered lawful. Persons driving a vehicle with a blue light must still drive the vehicle with "due regard" for the safety of other persons (s 58(3) and s 60). This means that the safety of other road users must be taken into account and that the driver of the privileged vehicle must be assured that other road users are aware of him (s 60(a); Hoctor Coopers Motor Law (2009) B9-6-B9-6A; and S v Groep supra 539B). It is evident from case law that, where "due regard" is not had to the safety of other persons, the exemptions will not be applicable to the drivers of privileged vehicles, which would include SAPS blue-light brigades, and such 
members may be found guilty of reckless or negligent driving ( $S \vee$ Groep supra 538; and S v Grobler 1992 (1) SACR 184 (C)).

\section{The application of the National Road Traffic Act 93 of 1996 to SAPS VIP Blue-light brigades regarding reckless or negligent driving}

The National Road Traffic Act 93 of 1996 provides that it is an offence for any person to drive a vehicle recklessly or negligently on a road. (S 63(1). S 58(3) provides that the safety of other road users must be taken into account. See Burchell Principles of Criminal Law (2005 revised 2008) 904 for a discussion on the distinction between recklessness and negligence. Recklessness is the grosser form of negligence. Note that Burchell's South African Criminal Law \& Procedure Vol 1: General Principles of Criminal Law (2011) is also referred to in this article and will be cited as Burchell South African Criminal Law \& Procedure Vol 1. See also the discussion in Hoctor Coopers Motor Law B11-1. In $S v$ Groep supra the appellant was a police officer who was convicted of negligent driving of a police vehicle after responding to an emergency and who had driven through a traffic-light controlled section while the traffic lights were against her (538C-D). Her appeal was dismissed as it was held that she had not driven with "due regard" for the safety of other road users. Jones, J states that the driver of the privileged vehicle must "be satisfied that all cross-traffic is aware of his presence" $(539 \mathrm{H}-\mathrm{I})$. See also $S v$ Grobler supra 185D, where a young constable was found guilty of reckless driving and $S v$ Kwadira 1982 (4) SA 291 (ZS), where the driver of a fire-engine was found guilty of negligent driving.) Section 63(2) of the National Road Traffic Act 1996 provides that a person will be deemed to have driven recklessly if such person drives "in wilful and wanton disregard for the safety of persons or property". Burchell states that reckless driving includes "inconsiderate" or "careless" driving which might pose a "risk of harm" to other drivers (Burchell Principles of Criminal Law 904). Recklessness may include inadvertent or advertent negligence or a situation where a person drives in such a manner that another person is frightened (Burchell Principles of Criminal Law 904 and 905; see further Burchell South African Criminal Law \& Procedure Vol 1 382-386, for his discussion and criticism of recklessness; see also $S \vee V a n$ Zyl 1969 (1) SA 553 (A) 559E; Hoctor Coopers Motor Law B11-5-B11-15; in such a case assault may also be committed; and see par 42 below). Where a VIP member drives inconsiderately such driving could be regarded as a form of reckless driving in that there is a disregard for the safety of other road users. VIP members could also be held liable for gross negligence where they pose a threat to property or persons $(S \vee$ Sweigers 1969 (1) PH H110 (A); and see also Hoctor Coopers Motor Law B11-12 and discussion at B11-16-17). Gross negligence is present where there is "a marked departure from the standards by which responsible and competent drivers habitually govern themselves" (Hoctor Coopers Motor Law B11-8; and a key factor which is mentioned in $s 63(3)$ that will be considered in the determination of whether s 63(1) has been contravened is the manner in and speed at which the vehicle was driven). 
An important point to take cognisance of is that the term "reckless" could include intention in the form of dolus eventualis. (Hoctor Coopers Motor Law B11-7 and B11-12. As Hoctor states: "The reason is that recklessness in its ordinary usage includes an appreciation of risk and those cases in which it was stated that 'recklessly' means no more than a gross or aggravated form of negligence were concerned only with the problem whether gross negligence could constitute recklessness" (B11-7). See also $s$ 63(2) of the National Road Traffic Act 1996; and S v van Zyl supra 557B-D.) Dolus eventualis is a form of intention whereby the:

"unlawful act or the causing of the unlawful result is not the main aim but: (a) he subjectively foresees the possibility that in striving towards his main aim, the unlawful act may be committed or the unlawful result may be caused and

(b) he reconciles himself to the possibility". (Snyman Criminal Law (2008) 184.

Burchell South African Criminal Law \& Procedure Vol 1369 defines dolus eventualis as existing "where the accused foresees the possibility that the prohibited consequence might occur in substantially the same manner as that in which it actually does occur, or the prohibited circumstance might exist and he or she accepts this possibility into the bargain (i.e. is reckless as regards this possibility)".)

Snyman equates (b) with recklessness (Snyman Criminal Law 184). A VIP member could therefore arguably be found guilty of a crime such as assault, assault with intent to cause grievous bodily harm or even murder if all the elements of these crimes are present, including dolus eventualis, which would presuppose intention, and if there is reckless acceptance of the risk. In order to be held liable for culpable homicide, which requires negligence, one would need to establish whether a reasonable person would have foreseen the possibility that someone might be killed as a result of the driving, whether the reasonable person would have taken preventive steps and whether the conduct of the accused differs from that of a reasonable person. (Hoctor Coopers Motor Law C1-3. See Burchell South African Criminal Law \& Procedure Vol 1 432, where he discusses the imperitia culpae adnumeratur principle whereby a lack of skill may amount to negligence in circumstances where a person engages unreasonably in conduct which could pose a risk to others. As Carlin aptly states in this regard: "The factors considered should not be limited to whether an officer used his emergency lights and siren or acted pursuant to statutory law. An officer can act within the law and still behave unreasonably and negligently". Carlin "High-Speed Pursuits: Police Officer and Municipal Liability for Accidents Involving the Pursued and an Innocent Third Party" 1986 Seton Hall LR 101 and 121.) Where a VIP member is found guilty of reckless driving the penalty is higher than it would be for another person found guilty of negligent driving (ss 89(5)(a) and (b)).

\section{Investigating criminal infractions for bullying that may be committed by VIP units}

Aside from the possibility of being found guilty of reckless or negligent driving (see $S \vee$ Groep supra (negligent driving); and $S \vee v$ Grobler supra (reckless driving)), if it is proved that there was no due regard for the safety of other road users, a number of other crimes could also be committed 
where other road users are bullied for right of way. (See Snyman Criminal Law 30-33. The VIP member could be charged in terms of traffic offences, as well as for the commission of other crimes in terms of the ordinary principles of criminal liability. The requirements of legality, conduct, compliance with the definitional elements of a crime, unlawfulness and culpability must be met. On a charge of murder or culpable homicide in such a case, it could be argued that the VIP vehicle was the cause of the accident. In materially-defined crimes such as murder or culpable homicide, both factual and legal causation must be proved. The requirement of unlawfulness must also be complied with, which means that no ground of justification should be present such as necessity, private defence or official capacity. The requirement of culpability must also be met. One should bear in mind that intention in the form of the requirement of dolus eventualis is sufficient on a charge of murder. Where negligence is present, a charge of culpable homicide could be laid. See Snyman Criminal Law 80-88, 95-30 and 149-187; and Burchell South African Criminal Law \& Procedure Vol 1 93-181, 353-393 and 422-432.) The discussion below will be confined to three crimes that could possibly relate to blue-light brigade bullying. These are the crimes of public violence, assault and intimidation in terms of the Intimidation Act 72 of 1982.

\section{Public violence}

Public violence may be defined as the "unlawful and intentional commission, together with a number of people, of an act or acts which assume serious dimensions and which are intended forcibly to disturb public peace and tranquillity or to invade the rights of others". (Snyman Criminal Law 321; and Burchell Principles of Criminal Law 867. It could be argued that driving a vehicle in such a manner that other vehicles are forced off the road, constitutes a disturbance of the public peace. Even if this is not so, the mere intention to disturb the public peace would be sufficient.) This crime can be committed clearly if the rights of others are invaded, but it is accepted that the conduct must be of a sufficiently serious nature (Burchell Principles of Criminal Law 867-871; and see also $R$ v Cele 1958 (1) SA 144 (N) 152153). A main issue would be whether the driving down of a public highway for kilometres on end at high speed, forcing other road users off the road, may in fact constitute an act of serious dimensions which invades the rights of others. (A further aggravating factor could be if such driving is not in the execution of the driver's duties and if there is a lack of due regard for the safety of other road users. Such activities would accordingly be rendered unlawful in terms of the NRTA as well. One of the functions of sanctions for the crime of public violence is to punish a "commotion" which presents "a danger to the person, property, or civil rights of the members of the public". See Burchell Principles of Criminal Law 867.) While the interests protected are public peace and tranquillity, and the forcing of other road users off the road or causing a collision might arguably invade the rights of others, it would be open to debate whether these acts in fact do qualify as acts of public violence which are of a serious nature. There are three further difficulties in proving whether this crime has in fact been committed. 
Firstly, as Snyman points out, the fact that there is a threatened or intended disturbance of the peace even by a number of people is insufficient to constitute this crime as there must be actual or intended violence which is of a serious nature (Snyman Criminal Law 323). Some of the factors that may be considered in the context of whether the act is serious or not involving the number of persons, although there is no minimum number of persons required, and whether there were assaults on persons or damage to property caused (Snyman Criminal Law 323). As far as the requirement of intention is concerned, it should be noted that the mere intention to invade other road users' rights or disturb the peace is sufficient (Snyman Criminal Law 323; and Burchell Principles of Criminal Law 871).

Secondly, problems might arise in the context of such persons 'acting in concert' as there must be a common purpose amongst the members of the group to forcibly disturb peace and tranquility (Snyman Criminal Law 322). As far as invading the rights of others is concerned, it may perhaps be argued that the VIP-protection unit or brigade are a number of persons who act together, namely with a common purpose, which means that the acts of each of them can be imputed to the others (Snyman Criminal Law 322). One criticism that could perhaps be levelled against this argument revolves around the issue of how large a group needs to be in order to qualify as "a number of people acting together". It is open to debate whether a few policeman in a single patrol would qualify as a number of persons. However, if one considers that a brigade consists of a number of vehicles whose drivers act in concert, and who could possibly qualify as members acting together as a "number of persons" the problem of sufficient numbers is perhaps ameliorated. However, this being said, the emphasis does not appear to be on the number of persons involved as much as on the extent of the violence (Burchell Principles of Criminal Law 870).

Lastly, and also one of the most important issues, which merits consideration, is the ethos of the prohibition of the crime of public violence. Snyman views the crime of violence as one which is essentially a crime against the state; although he mentions that the interests which are protected are the public interest and tranquillity (Snyman Criminal Law 321). Burchell is of the view that the crime of public violence "maintains the community interest in public peace and good order" (Burchell Principles of Criminal Law 867). Whether this crime is couched in broad enough terms to cover instances of reckless driving where the public peace is disturbed is questionable as the act must also assume serious dimensions, which involves the use of violence as opposed to the application of force (Burchell Principles of Criminal Law 871). As Burchell explains, force is insufficient as it envisages energy being applied with the intention of moving an obstacle, whereas in contrast, violence connotes the application of physical force with the aim of inflicting harm to persons or their property (Burchell Principles of Criminal Law 870). Therefore it is doubtful whether a successful conviction will ensue should a charge of public violence be laid against the VIP brigade for the reasons highlighted above. 


\section{Assault}

Assault is defined by Snyman as:

"any unlawful and intentional act or omission

(a) Which results in another person's bodily integrity being directly or indirectly impaired, or

(b) Which inspires a belief in another person that such impairment of her bodily integrity is immediately to take place." (Snyman Criminal Law 455; and assault in this context could include assault with the intent to cause grievous bodily harm (461).)

The crime can be committed by the application of direct or indirect force or the inspiring of fear that force will be applied (Snyman Criminal Law 457458; and Burchell Principles of Criminal Law 684-685). With regard to the latter, the aim must be the "intentional inculcation of fear of bodily harm" and verbal threats are sufficient (Snyman Criminal Law 458-459; and Burchell Principles of Criminal Law 685-687.) As Snyman goes on to say, one should not focus too much on the type of act committed but rather on any omission or commission which results in the impairment of a person's bodily integrity (Snyman Criminal Law 460). In the context of blue-light convoys, the application of direct force could take the form of physical collision with another road user. The indirect application of force could take the form of forcing such road user off the road, which may or may not lead to a collision. The inspiring of fear could take the form of driving or behaving in such a manner that road user's fear for his/her safety or the safety of his/her passengers. If there is an intention to cause severe bodily harm, a prosecution for an assault with intent to cause grievous bodily harm could also ensue. (In the case of Joseph 1964 (4) SA 54 (RA) a truck driver deliberately drove towards a road user and although the truck did not hit the road user, the incident led to a finding of assault with the intent to cause grievous bodily harm.)

\section{Intimidation}

Section 1(1) of the Intimidation Act 72 of 1982 makes provision for an offence where a person:

"(a) without lawful reason 'intends to compel persons to' do or abstain from doing any act ...

(i) assaults, injures or causes damage to any person; or (ii) in any manner threatens to kill, assault, injure or cause damage to any persons ... or

(b) acts or conducts himself in such a manner ... that it has or they have the effect, or it might reasonably be expected that the natural and probable consequences thereof would be, that a person perceiving the act, conduct $\ldots-$

(i) fears for his own safety or the safety of his property ... shall be guilty of an offence and liable on conviction to a fine not exceeding [R200 $000]$ or to imprisonment not exceeding ten years or to both such fine and such imprisonment." 
While a charge could admittedly be laid under section 1(1) which is aimed at individuals, it is doubtful whether a charge of intimidation could be laid in terms of section $1 \mathrm{~A}(1)$, which also makes provision for a crime of intimidation. Unlike section 1(1) which is aimed at individuals, section $1 \mathrm{~A}(1)$ is aimed at the general public (Snyman Criminal Law 465). This latter section makes provision for an offence where fear is instilled into the general public or where an act of violence is committed or a threat of violence is uttered (s $1 \mathrm{~A}(1)(\mathrm{a}))$. The performance of any act which causes, brings about, promotes or contributes towards an act or threat of violence is also covered (s 1A(1)(b)). The difficulty in applying this section would centre on the issue of what constitutes the "general public". If this term is interpreted broadly, it could refer to general road users. However, it a narrow interpretation is adopted whereby the envisaged target public are the inhabitants residing next to the road, then it is doubtful whether this section would be applicable to situations of reckless driving. For a charge of intimidation to be prosecuted successfully it is clear that such charge should rather be laid under section 1(1) which will is aimed at the punishment of individuals.

\section{Grounds of justification}

Should VIP units be charged with an offence, they might rely on the provisions of 58(3)(a) of the National Road Traffic Act and aver that they fall within the exemptions of this section in that "due regard" was paid to the safety of other road users, or alternatively they may raise a ground of justification, which may exclude the unlawfulness of their actions. (Grounds of justification may be relied upon in both common-law and statutory offences. See Snyman Criminal Law 95-96 and Chapter IV.) Examples of grounds of justification that may be raised in this context are necessity, private defence and official capacity. These grounds will now be discussed.

\section{Necessity}

Necessity is a ground of justification that is raised when a person is "faced with human threats" or "overwhelming force of surrounding circumstances" which causes harm to innocent third parties or to their property (Burchell South African Criminal Law \& Procedure Vol 1 48; and Snyman Criminal Law 115). It must be necessary and it is not sufficient if the threat is only expected in the future, as it must be imminent or have commenced (Snyman Criminal Law 119-121 for a detailed discussion of the requirements of necessity). It is therefore clear that one cannot rely on necessity if the threat may only be encountered in the future. As Snyman states:

"Necessity is a ground of justification if $X$ finds herself in an emergency situation, has to weigh two conflicting interests against each other and then infringes the interest which is of less importance according to the legal convictions of the community, in order to protect the interest which is of greater importance" (Snyman Criminal Law 117).

Necessity cannot be raised in the case of an emergency situation which does not exist. If members of the VIP-protection unit raise the issue of fearing for their lives then so can general road users. Based on this 
argument and with crimes such as highjacking and murder forming a daily reality, we could all be speeding or ignoring road signs in order to protect our lives. "Putative necessity" is not a ground of justification. (It may, however, be used as a defence to exclude culpability. Snyman Criminal Law 121; and Burchell South African Criminal Law \& Procedure Vol 1418-419.)

\section{Private defence}

"Private defence" is the term used when a person uses force to repel an unlawful attack which has commenced, or is imminently threatening upon such person's or another's life, property, bodily integrity or other interest which deserves to be protected, as long as such defensive act is necessary to protect the interest which is threatened, is aimed at the attacker and is reasonably proportionate to the attack (Snyman Criminal Law 103; and Burchell South African Criminal Law \& Procedure Vol 1121). The question is whether it is justifiable to force other road users off the road in a manner which essentially pre-empts a possible future attack or potential threat even if no real threat of danger exists. As far as successfully raising this defence is concerned, one should bear in mind that it is not the innocent road user against whom this defence could be raised, but rather potential criminals or a criminal gang who could be regarded as the "attacker".

As pointed out earlier, every road user may also be subject to a possible highjacking or attack, which means that each road user could also contravene the road regulations under the pretext of "private defence". It is clear from the definition that the attack must be imminent and may be directed at a third party. There must be an immediate threat and not merely an expectation of a possible future attack (Snyman Criminal Law 106; and Burchell South African Criminal Law \& Procedure Vol 1 122). If the VIP brigade contravenes the road regulations in the absence of a real threat or danger, they are therefore acting unlawfully.

\section{Official capacity}

If a police member or member of the VIP unit performs an act in the execution of his or her duties arising from the office he or she holds, such person may be able to raise this ground of justification to exclude unlawfulness (Snyman Criminal Law 129-130). It is doubtful whether racing to a meeting or event for which the VIP is late falls within the definition of "execution of duties", although it was held in a very old decision that a post office official is not acting unlawfully if such person speeds in order to complete his/her tasks in time. (Snyman Criminal Law 13. See also Rex v De Beer 1929 TPD 104 115, where Feetham J held that the Provincial Council did not intend the ordinance in question ("An Ordinance for the registration of motor vehicles and the licensing of motor-vehicle drivers and in respect of other matters relating to the use of motor vehicles in this Province of Transvaal") to be binding on the Crown or on one of its servants acting in the execution of his duties and that such person could therefore not be convicted of exceeding the speed limit in terms of $s 11$ of this ordinance.) In stark contrast though, in the more recent case of $S$ v Fourie (2001 (2) SACR 
674 (C)) a regional court magistrate was found guilty of exceeding the speed limit where he had raised official capacity as a ground of justification. Msimang AJ held that the interests to be protected by the Road Traffic Act remain "the physical safety of the members of the public" (680) and that the act of speeding by the magistrate "cannot be countenanced by the legal convictions of the community" (681).

\section{Constitutional issues applicable to high-speed pursuits and VIP blue-light brigades}

The last aspect which will be considered is whether the Constitution of the Republic of South Africa, 1996, provides any solution to VIP members acting with impunity. The Constitution clearly states that some of the objectives of the police service include the prevention, combating and investigation of crime, the maintenance of public order and the protection and securing of (all) the inhabitants of the Republic as well as their property (s 205 of Act 108 of 1996). A fundamental question is whose interests are predominant: a select few who are protected by a VIP unit or the general community of road users?

The Constitution provides in section 3(1) that all citizens are equally entitled to the rights of citizenship and have the duties and responsibilities of citizenship. The Bill of Rights "applies to all law" (s 8(1)) and "everyone is equal before the law and has the right to equal protection and benefit of the law" (s 9(1)). The state may not discriminate unfairly against anyone on the basis of various grounds $(9(3))$. Furthermore everyone has the right to freedom and security of the person in terms of section 12, which includes the right "(a) not to be deprived of freedom arbitrarily or without just cause, ... (c) to be free from all forms of violence from either public or private sources and ... (e) not be treated in a cruel, inhuman or degrading way".

From a constitutional-law perspective much can perhaps be said regarding the immunity provisions afforded SAPS members which are provided in sections 58(3) and 60 of the National Road Traffic Act which, are currently so broadly couched that VIP members fall within the exemption. Rights may be limited in terms of section 36 of the Constitution. This section provides that rights may be limited if this is reasonable and justifiable in an open and democratic society based on human dignity, equality and freedom. (The factors which must be taken into account in section 36(1), include the nature of the right, the importance of the limitation, the nature and extent of such limitation, the relation between the limitation and its purpose and the possibility of using less restrictive means to achieve the purpose.)S 41 of the Constitution holds that "all spheres of government and all organs of state within each sphere must preserve the peace, national unity and the indivisibility of the Republic; secure the well-being of the people of the Republic; provide effective, transparent, accountable and coherent government for the Republic as a whole". The well-being of all citizens and not merely that of a select few, along with accountability, is therefore a key issue that should not be lost sight of. The right to dignity may be violated depending on the manner in which the VIP brigade proceeds. 
Whether these provisions in the National Road Traffic Act could in fact be struck down realistically is questionable, as there is undoubtedly a need for exemptions to be applicable to emergency vehicles. However, the provisions are broadly phrased and therefore VIP members also fall within the scope of the exemption. An alternative means which could perhaps be considered, and which may ameliorate the problem, is to test the administrative decision to employ such VIP units against the Constitution instead. Section 33 provides for just administrative action and allows a court to provide for the review of any administrative action (s 33(3)). Section 195 also provides that public administration "must be governed by the democratic values and principles enshrined in the Constitution" which principles also include the accountability of public administration (s 195(1)(f)).

The Constitution of the Republic of South Africa, 1996, provides that members of the Cabinet and Deputy Ministers may not act in any manner which is inconsistent with their office, nor may they expose themselves to any situation involving the risk of a conflict between their official responsibilities and their private interests, and they may also not use their position to enrich themselves. (Ss 96(2)(b) and (c). See Schulz-Herzenberg and Vickerman "Financial Disclosure requirements in South Africa 20042008" Institute for Security Studies ISS Paper 192 (August 2009). While the paper focuses on accountability by politicians, the authors mention that the misuse of public property could also amount to a conflict of interest (3) which could also possibly by analogy be used in circumstances where blue-light brigades are used to further personal interests.) In addition, MECs and members of the Cabinet are bound by a Code of Ethics which contains a number of provisions embodied in the Constitution relating to accountability. This Code in fact specifically states that "the Constitution provides a minimum content for the envisaged code of ethics" and reference is made to sections 96(2) and 136(2) of the Constitution. (The Code makes specific mention of the Executive Members' Ethics Act 82 of 1998, which Act in section 2 also gives effect to sections 96 and 136 of the Constitution. It furthermore provides that the Public Protector must investigate alleged breaches (s 3). See Code of Ethics of the Cabinet and Members of Executive Councils http://www.pmg.org.za/minutes/20000522-code-ethicscabinet-mec (accessed 2012-07-17).)

According to the SAPS crime statistics for April 2010-March 2011, 2071 487 serious crimes were registered, with contact crimes accounting for $30,8 \%$, contact-related crimes for $6,4 \%$, property-related crimes for $25,8 \%$, crimes attributable to police action for $11.2 \%$ and other serious crimes for 25.8\%. (See SAPS Crime Statistics available at http:// www.saps.gov.za (accessed 2012-07-17)). While persons who enjoy VIP-protection status may fear for their lives, general road users are similarly faced with potential threats of harm to their lives such as highjackings and murder. Road signs in fact warn of "high-jacking hotspots". Less restrictive means of protecting VIPs could be to identify key VIPs such as the President and Deputy Presidents, who are high-profile individuals who require protection, and perhaps a few select individuals such as high-profile political party leaders whose lives may also be in danger from real and not putative or potential threats. If the number of VIP body guards were limited it would leave 
additional SAPS members free to combat violent and other crimes on a daily basis. Case-law also dictates that the state has a duty to protect (all) citizens from violent crime and to protect all citizens' fundamental rights and may be held accountable should it fail to do so. (Carmichele $v$ Minister of Safety and Security 2001 (4) SA 938 (CC); and Minister of Safety and Security v Van Duivenboden 2002 (6) SA 431 (SCA) are cases in point. The Constitution provides in S 199(5) that security services (defence force, police service and intelligence services) must teach and require their members to act in accordance with the Constitution and the law. S 205(3) further provides that the objectives of the SAPS that would include VIP members are to "prevent, combat and investigate crime, to maintain public order, to protect and secure (all) the inhabitants of the Republic and their property, and to uphold and enforce the law" (emphasis added).) The possibility of vicarious liability on the part of the state is therefore not excluded and would also serve as a measure of accountability in holding the state liable for MECs' and VIP members' conduct unless it could be argued that the conduct did not fall within the course and scope of the employment relationship. (It should be noted that vicarious liability is only possible in statutory crimes. See Snyman Criminal Law 250-251 in this regard)..)

\section{Conclusion}

Where VIP members act in contravention of statutory traffic laws and the exemptions are not complied with, they are obviously acting unlawfully and may be found guilty of reckless or negligent driving or other crimes. Where there is bullying behaviour in the form of inconsiderate driving, it has been shown that this can be considered to be a disregard (that is, no due regard) for the safety of other road users and the exemptions in sections 58(3) and 60 of the National Road Traffic Act 93 of 1996 would consequently not be applicable. The drivers of these privileged vehicles may, however, also be charged with other crimes to which they may still raise a ground of justification such as necessity, official capacity or private defence to exclude the unlawfulness of their actions (Snyman Criminal Law 117).

While the VIP units may possibly be caught under the net of general statutory and common-law offences, perhaps both national legislation and/or provincial regulation that more specifically regulates VIP brigades would be a pre-emptive measure that would go a long way towards promoting roadtraffic equality. This would create an additional safety measure to ensure that the principles governing security services which are enshrined in the Constitution are upheld (s 198 states that: "national security must reflect the resolve of South Africans, as individuals and as a nation, to live as equals, to live in peace and harmony and to be free from fear ...").

Charnelle van der Bijl University of South Africa (UNISA) 